\title{
The Framework of Teacherhood in Art Education
}

\author{
Kaarina Määttä ${ }^{1} \&$ Satu Uusiautti ${ }^{1, *}$ \\ ${ }^{1}$ Faculty of Education, University of Lapland, Rovaniemi, Finland \\ *Corresponding author: University of Lapland, Finland. Tel: 358-40-484-4167 E-mail: satu@uusiautti.fi
}

Received: March 4, $2013 \quad$ Accepted: April 3, $2013 \quad$ Online Published: April 15, 2013

doi:10.5430/wje.v3n2p38 URL: http://dx.doi.org/10.5430/wje.v3n2p38

\begin{abstract}
In Finland, art teachers are currently trained at the Aalto University, Helsinki, and at the University of Lapland, Rovaniemi. This review is based on research on and other literature discussing art education. In addition, experiences of art teacher education program provided at the University of Lapland provided the basis of our analysis of the essence of teacherhood in art education. Our purpose in this article is to review the theoretical and practical basis of teacherhood in art education. We will discuss the phenomenon from two points of view: What internal and external factors does teacherhood in art education theoretically and practically consist of? Through answering these questions we aim at creating a model of the framework of teacherhood in art education that can help the study and development of art education and art education teachers' training.
\end{abstract}

Keywords: art education; teacherhood; art teacher; professional identity; professional role

\section{Introduction}

Teacherhood in art education is quite a multidimensional concept that changes all the time and finds new forms (Siegesmund, 1998; Tatto, 2006). Art education has a long history: in Finland, the roots hark back to the drawing education of the 19th century. Art teachers have been educated in Finland since 1915 when the contemporary School of Arts started providing courses for drawing teachers in Helsinki. In 1961, art education became a major in art teacher education (Pohjakallio, 2005). At the moment, art teachers are trained at the Aalto University, Helsinki (the former School of Arts) and at the University of Lapland, Rovaniemi, in Finland.

At the University of Lapland, art teacher education started in 1990 when the Faculty of Art and Design initiated education program aiming at a Master's degree in art and majoring art education. One of the authors of this article, Prof. Määttä, has been working with this education program from its very first years and has developed research of art education. Research is consciously selected as a salient part of art education teacher training programs.

Department of Art Education at the University of Lapland offers a Master's degree programme in visual arts education. Graduates are qualified to teach art in the comprehensive schools, upper secondary schools, vocational schools, and in visual art schools for children and the youth. The department of art education has defined the core areas of research in art education: The major in art education consists of cumulative modules in practical art education, image theory, artistic expression, and research (University of Lapland, 2013).

This article is based on the long-term teaching and research experiences at the Faculty of Art and Design (see Määttä, 1994; 1998; 2001). Experiences of art teacher education program inspired us to discuss and analyze the essence of teacherhood in art education. The special features of art teachers' work have been studied abundantly (e.g., Eckhoff, 2008; Eisner, 1972, 1989, 2002; Gude, 2004; Laitinen, 2006) along with the special features of art education (e.g., La Porte, Speirs, \& Young, 2008; MacDonald, 1998; Paksuniemi, Uusiautti, \& Määttä, 2012), but a holistic picture of the teacherhood in art education has remained undefined.

Our purpose in this article is to review the theoretical and practical basis of teacherhood in art education. We will discuss the phenomenon from two points of view: What factors does teacherhood in art education theoretically consist of? How do these factors direct art teachers' practical work? This review is based on research on and other literature discussing especially art teachers' work. In addition, personal experience and dozens of Master's theses supervised in art education support our review (see Määttä, 2001). 
Through answering these questions we aim at creating a model of the framework of teacherhood in art education. This framework includes two dimensions: (a) the theoretical elements of art teachers' work or the so-called external factors and (b) detailed practical factors directing art teachers' work, internal factors, or the so-called core factors. The fundamental idea is that teacherhood in art education consists of these external and internal factors.

Being based on our own experiences and precomprehension of the phenomenon, this review has a hermeneutical nature (Gadamer, 2004; Kakkori, 2009). According to Bingham (2009), a hermeneutic analysis of education can store a serious critique for current practices in education. In this process, our interpretation of art teachers' and students' action has a salient role. In other words, we interpret the essence of teacherhood in art education from our own point of view and by simultaneously leaning on previous research. We follow the idea of Lawrence Stenhouse who launched the teacher as researcher movement: reflection of one's own action and discussing it help teacher-researchers' to become aware of their own values and analyze and change theories that direct their everyday work (see May, 1993). Moreover, we lean on Elliot Eisner's (1991) thoughts as he recommends taking theories with a flexible mind and using them as eclectic tool for the purposes of interpretation. By creating the framework of teacherhood in art education, we want to show the context of the phenomenon as comprehensively as possible through the dialogue of practice and theory and through introducing new questions. Figure 1 illustrates the elements of teacherhood in art education. Next, we will discuss them in detail. First, we introduce the external factors that define teacherhood theoretically, but the main emphasis in our analysis will be on the internal or practical factors that are the art teacher as a personality, as an expert, and as a colleague to other teachers.

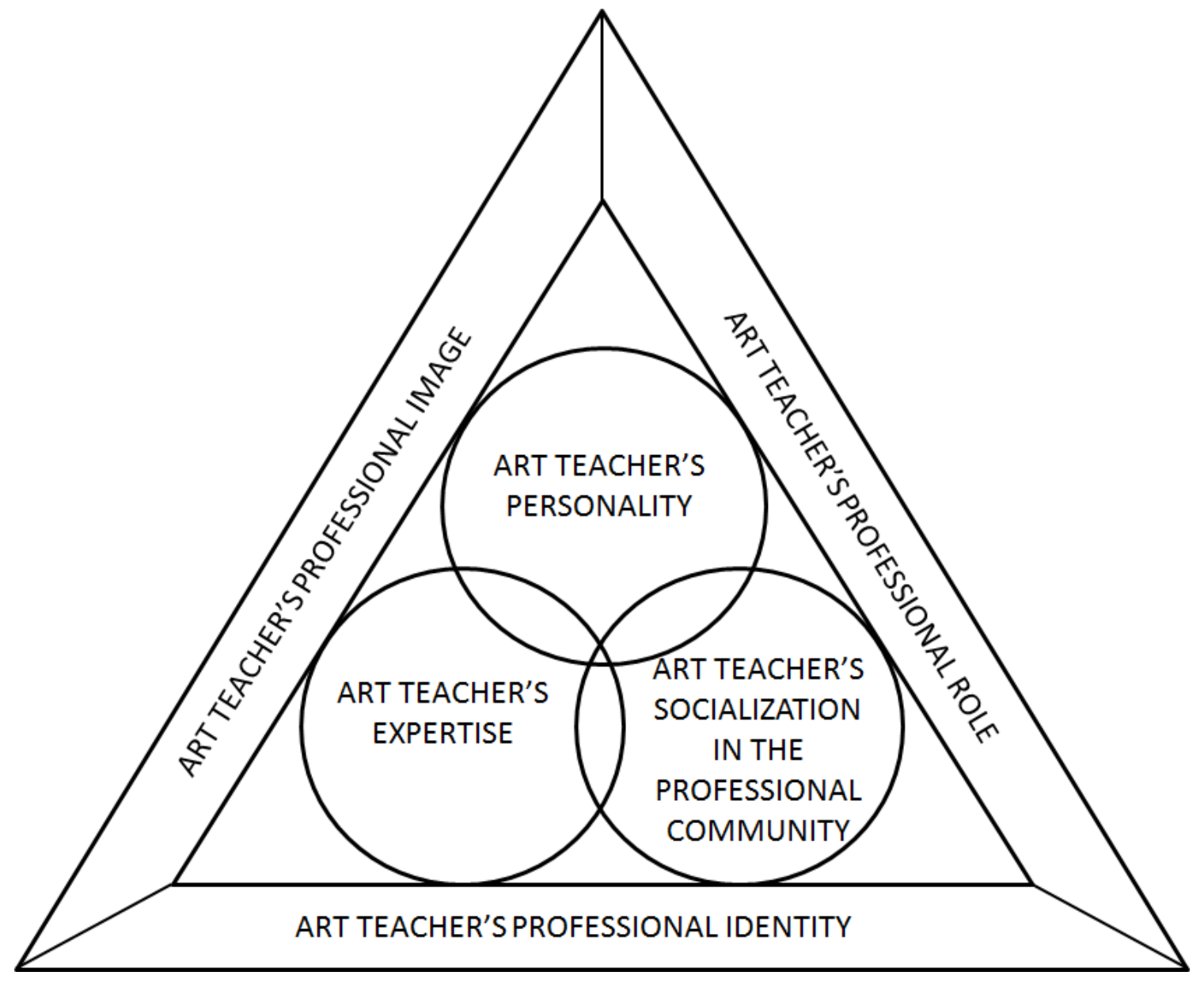

Figure 1: The Framework of Teacherhood in Art Education

\section{External Factors of Teacherhood in Art Education}

Teacherhood in art education consists of three theoretical or external factors (1) the professional image of an art teacher, (2) the adoption of the professional role, and (3) the adoption of the professional identity. Naturally, 
teacherhood in art education has similarities and differences with teacherhood in general (Williamson McDiarmid \& Clevenger-Bright, 2008).

\subsection{Professional Image}

Professional image includes tasks and duties the profession involves and those various prerequisites, skills and knowledge, that one has to possess in order to be able to work as an art teacher. The professional image of an art teacher is molded by the expectations and demands set by teacher self and the environment. Written decrees and curricula and school-specific goals and methods set their own framework for teaching. In addition to official requirements and expectations, unwritten norms are reflected to the art teacher's professional image (Korkeakoski, 1998).

\subsection{Professional Role}

The internalization of teacherhood is a long process preceded by professional growth and development (Beijaard, 1995; Ruohotie, 1996). Actually, the process of becoming a teacher begins from one's own school time, continues during teacher education and when entering work life. Indeed, teachers go through a triple socialization process (Uusiautti \& Määttä, 2013). As a result, one considers the role of an art teacher as a natural part of one's life (see also Garvis, 2012) and has found one's professional role as a teacher. The teacher is aware of his or her character as a teacher, how he or she perceives the art teacher's work, and how he or she is able to confront the demands of the work (Beijaard, Meijer, \& Verloop, 2004).

\subsection{Professional Identity}

Teacherhood in art education is also connected to professional identity. A clear professional identity develops along favorable professional growth during art teacher training. After successful adaptation of the professional identity and professional role, the art teacher becomes convinced that he or she knows the job and is suitable to the profession (cf. Lindfors, 2010). The art teacher has adopted the necessary readiness, knowledge, skills, and motivation. The teacher is also realistically aware of his or her own possibilities and restrictions and has the wish to develop himself or herself and the profession. The professional identity also includes the adoption of professional ethics and acceptance and following of the ethical principles. Art teachers have "artistic freedom", but also they have to adopt the roles school work sets for them (Thornton, 2011).

Teacherhood in art education develops along with professional growth. The phases of teachers' professional development have been described from the points of view of various contents and as constantly renewing (Daichendt, 2011). Next, we will discuss the features of art teachers' practical work that form the core of teacherhood in art education.

\section{The internal Factors of Teacherhood in Art Education}

The most essential internal factors of teacherhood are (1) the teacher's personality and individual characteristics, (2) the expertise and professional skills of art and education, and (3) socialization into the professional community. They can also be considered the core factors or practical factors of teacherhood.

\subsection{Personality and Individual Characteristics}

A significant part of teacherhood and professional development in art education is the development of personality covering both the individual growth and the development of a teacher's personal characteristics in a pedagogical sense. One outcome of the personal development is a teacher's personal teaching style that a teacher develops in order to handle the everyday work as a teacher. The style consists of a series of a teacher's own choices and experiments. The personal style separates the teacher from thousands of other teachers (Pavlou, 2004).

In Finland, Uno Cygnaeus emphasized already in the 1860s a teacher's own being as the guarantee of successful education. The teacher's decency is the best guarantee for the realization of educational purposes. The teacher's personality was supposed to manifest compassion, love, and patience toward pupils (Cygnaeus, 1910; Määttä \& Uusiautti, 2011). Similarly, van Manen (1991) asks: "Is it possible to act as a real teacher if one is not oriented to children with loving care, trustful hope, and responsibility?" (p. 65).

Numerous educationalists have emphasized the significance of the teacher's personality (e.g., Korthagen, 2004; Zombylas, 2007). Still, different eras, theories, ideologies, and conceptions of a human being have their own emphasis on good teacherhood and educatorship (Määttä \& Uusiautti, 2001). Moreover, art teachers have to constantly reflect on whether they are more like teachers or more like artists. This question has been a part of 
teacherhood in art education already for a long time (Anderson, 1981; Ball, 1990).

Although it is impossible to create an ideal image of an art teacher's personal features, the importance of the teacher personality is worth emphasizing in an art teacher's work, too (Murray et al., 1990; Räsänen, 2009). Teacherhood is a relationship profession in which personality is one of the teacher's tools. Teachers' work involves plenty of emotional strain and inevitably teachers have to face frustration in their work. There are situations in which teachers feel having failed regardless of the solution they make. They face various problems and challenges that do not have any ready solutions. In this sense, teaching has points of resemblance with artistic work. Alongside successful insights, teachers have to tolerate unsatisfying solutions as well.

Frustration and experiences of failure can result from attempts to lead pupils' learning. Even if the teacher was skillful and talented, pupils will not necessarily learn. The teacher's most important task is to help pupils develop, learn, create, and become enthusiastic. Pupils' learning is not only explained by teachers' action, activity, or enthusiasm. Learning results from pupils' own active action (Määttä \& Uusiautti, 2011).

Good teachers perceive their work and themselves realistically. Likewise, art teachers must face many kinds of demands and strain by the official regulations and rules directing teaching and education and by pupils, pupils' parents, and school authorities. In addition, the reality of art education is quite multidimensional and rich in content, and cooperation with the art circles is important (see e.g., Garnet, 2012). An art teacher has to work between a rock and a hard place, and thus, it is important that the teacher's own personality is not overly strained. Art teachers have to have good self-knowledge and a positive self-image. They have to be able to find the limits of their own abilities and talents so that their professional knowledge is comprehensively utilized. It is important to be able to defuse the tension between one's personality and professional role without losing the belief in being capable of coping with the challenges of teaching.

A good teacher is a one-of-a-kind personality who does not behave or apply methods mechanically. Luckily, teachers who are known as good ones differ from each other considerably when it comes to their personal characteristics. It would be impossible to think of a prototype teacher who would behave in a certain manner: teachers are different, but so are pupils (see Määttä \& Uusiautti, 2011).

\subsection{Expertise and Professional Skills}

Experise is based on the mastery of the substance matter of art education. Professional skills are connected to the design, realization, and evaluation of teaching processes and other didactic skills. Metacognitive skills develop, too. Along with them an art education is able to conceive the content of the educational field they have specialized in and can apply their knowledge better and better. In addition to expertise in the specific school subject, teachers have to be pedagogical and didactic experts (Beijaard, Meijer, \& Verloop, 2004).

Expertise develops through work years and in-service and continuing education (Thornton, 2005). Reflective teachers can analyze various school and teaching practices and their own fixed belief critically. Professional growth in teaching work and teacherhood requires reflection, questioning, and problematizing (Boud, Keough, \& Walker, 1989).

Art teachers' expertise originates in teachers' ability to promote pupils' development according to the goals and contents of art education (Jolley \& Zhang, 2012; Kirlew, 2011). The purpose of the subject of art education is to learn about visual arts, cognizance of art, imagery, and environmental esthetics (Korkeakoski, 1998). Art learning is based on a holistic conception of learning. Art education can help pupils to process their perceptions and experiences through sensory, conceptual, and operational knowledge. Artistic action covers many forms of knowing, thinking, experiencing, and doing on which pupils' own artistic expression is built (Pohjakallio, 2005).

Art teachers' professional skills are manifested through their ways of realizing teaching and learning processes. These teaching skills also consist of many kinds of factors (Määttä \& Uusiautti, 2011). Along with mastery of art and pedagogical and didactic skills, teaching is influenced by educational awareness, conceptions of teaching and learning, acquaintance with pupils, interaction skills, etc. Teachers also have plan their work perseveringly, evaluate teaching and learning, be familiar with teaching methods, and be able to mold their teaching flexibly (Räsänen, 2005). Teaching of art has many similarities with any other teaching work but it also have many unique challenges (see e.g., Stanhope, 2011).

The most essential expertise in art teachers' work includes naturally artistic skills and creativity (Daichendt \& McDougall, 2011) and ability to get pupils throw themselves in the world of creativity (De Backer et al., 2012). Westerman (1991) defines the teaching event as a complex series of congitive operations directed by the teacher's thinking and decision-making (see also Randles, 2009). Parsons (2012) also points out that the teacher may confront 
difficulties in mastering cognitive operations required in teaching if the teacher does not comprehensively understood teaching per se and does not know enough various solutions which he or she could use as the basis for decision-making.

What are, then, these operations and decision-making situations that are involved in teaching? At the micro level, teaching as classroom-based action requires (a) planning before a teaching situation, (b) solutions of how to realize teaching during a teaching situation, and (c) solutions of how to evaluate teaching after a teaching situation.

a) Planning before the teaching situation

When planning teaching, the teacher has to apply the curriculum, set goals, plan the usage of time, and make choices over the theme of a lesson, materials, and methods. In order to make successful solutions, the teacher has to have an understanding of what is important in teaching, what themes should be emphasized, how the themes are intertwined, and how to transform the goals and their contents into teaching. Although the art teacher is profoundly aware of the subject, he or she still has to make many kinds of decisions and choices (see Hunt \& Handsfield, 2013; Schmidt \& Canser, 2006).

The subject of art sets unique demands on the planning of teaching. Indeed, Finnish teachers seemed to regard the imbalance between scanty material resources and diverse objectives and the lack of time allotted to art education as a great challenge. There is much to teach but not enough time. Art education belongs, alongside other art and practical subjects, to the so-called marginal subjects at school when it comes to its time allocation although the importance of the subject to pupils' favorable development has been recognized (Anttila, 2006).

The general objectives of art education can be set from many perspectives depending on, for example, the position and significance of art and the task of art in society (Atkinson, 2012). On the other hand, the objectives of art education can be defined based on the meaning of the subject to individuals and their development. And there are many other ways of setting the goals.

Art education has many faces (Lindström, 2011). What is art education: education of artistic subjects, education taking place in the field of art, or cultural education leaning on art (Huuhtanen, 1984)? It can be mainly society-oriented (the reconstructionist trend), child-centered (the expressionist trend), or subject-centered (scientific rationalism) (e.g., Eisner, 1972). Furthermore, the wider goals of art education can be education through art (art education provided by school), education for art (education of the audience and the role of criticism), and education into art (education of artists) (see Lindström, 2012).

An art teacher has to consider the aforementioned and many other viewpoints when setting goals for his or her education work. Obviously, the educational goals of art education resemble the same complexity that authentic artistic action has. Given this perspective, there are many kinds of possible solutions to realize art education and promote learning in the best possible manner (Hall, 2010).

b) The realization of teaching

In a teaching situation, a teacher implements the teaching plan in practice. This also requires decision making (Watts-Taffe et al., 2013). What happens in a classroom is not often predictable nor is it always easy to adjust the materials in the practical situation (Addison, 2011). The possibilities to work with art and the contents of art education are so diverse that pupils' reactions cannot always be foreseen (Clayson, 2008). The planned structure of a lesson or pupils' reactions does not go as planned. When the teacher is familiar with the subject, he or she is able to be flexible and adjust to teaching situations. Art teachers find pupils' experiences of inspiration when learning about art the most inspiring and encouraging (see Page, 2012). And not just the familiarity with the contents of the subject but didactic and pedagogical skills, optimistic attitude, and strong trust in pupils' abilities and desire to learn will lay a solid foundation to the practices of art education (Irwin \& O'Donoghue, 2012).

Art education and creative activity require special premises. If the school does not have functional teaching premises, the possibilities of art education are restricted (Wild, 2011). Workshoplike working, handling of various materials, storing of materials, tools, and artworks, and maintenance of tools set special conditions to the premises and equipment.

c) Evaluation

After a teaching situation, the teacher has to decide how to evaluate his or her own work and pupils' action. The former means the teacher's reflection on his or her own solutions, methods, and beliefs, and if necessary, his or her ability to question them. Through reflection, the teacher can create new objectives and methods to develop his or her teaching (Jarvis, 1999; Zeichner \& Noffke, 2001). The evaluation of pupils provides the teacher and pupils with 
feedback of what was learned. Successful evaluation can encourage and guide future learning, too (Hounsell, 2003).

However, in art education, evaluation of visual expression and art is quite problematic. Evaluations must be objective. It can be diagnostic, formative, or summative; absolute or relative; qualitative or quantitative. The target of evaluation in art is often the quality of visual production and arouses many questions: What is considered quality? Who can define quality? What kinds of qualitative features are emphasized in evaluation? What are the concepts of describing quality? How does the teacher justify his or her quality-related opinions? To what extent is art based on a subjective experience; to what extent can objectivity be expected in evaluation? (Kangas, 1995.) Even professional art critics can analyze the piece of art under evaluation from several points of view. This is exemplified for example in Anu Uimonen's (1994) article in which she described the public discussion about Mari Rantanen's painting.

Consequently, it is possible - and even necessary - to obtain evaluations from various sources and with various methods. Triangulation can function as the guarantee of the rightness of evaluation. Eisner (1991) presented three criteria of good qualitative evaluation that increase reliability and credibility: coherence (the unity of various targets of evaluation), consensus (congeniality among the targets of evaluation), and usability (the usefulness of the targets of evaluation). The aforementioned criteria can also be misleading: the teacher can only focus on those features that support his or her preconceptions and be blind to other features.

The reliability of evaluation is difficult also because a piece of visual art is quite multidimensional. It always has the emotional, evocative, or experiential dimension, and, on the other hand, the material and formal dimensions. A picture always has content and form. How to pay attention to all these dimensions when evaluating the process of making the piece and the ready product? (See Efland, 2004; Eisner, 1989.)

Eisner (1972) distinguishes the concepts of evaluation, testing, and criticism from each other. One form of evaluation is art criticism that according to Eisner's definition can be divided into descriptive, interpretative, and evaluative criticism. In all forms of criticism, verbal expression is salient. Evaluative criticism always focuses on the quality of product. The form of evaluation includes five viewpoints. Ritva Kangas (1995) has analyzed these points in the light of how class teachers and artists evaluate children's drawings and paintings:

1) The experiential viewpoint: How does the work of art affect feelings, how does one react to the work of art?

2) The formal viewpoint: How are the visual factors connected with each other, how harmonious the work of art is?

3) The material viewpoint: What is the relationship between the materials and formation, theme, and expression?

4) The thematic viewpoint: What is the idea behind the work of art? What is the content behind the visual and formal information?

5) The contextual viewpoint: What is information involved in the work of art in this context and era and from this artist?

Art teachers can be paralleled with critics with powers of observation. They have to be able to see what is qualitatively significant and how quality consists of various components and relations. Art teachers' and critics' task is to make structures, themes, and forms visible and to show how to see more deeply, notice more, and arouse new and personal questions about the work of art in the one seeing it (St. John, 1985). Criticism as a concept is multidimensional: it can be public discussion or feedback given by a singular art teacher to a pupil or a group of pupils. Group-based criticism is typical of art education.

Verbal evaluation of visual phenomena leans of certain quality criteria. Nevertheless, these criteria always include personal interpretation, views, knowledge, and experiences that affect how one experiences the work of art. In fact, the history of art knows artists who have not wanted to verbalize their works of art in order to make room to the art viewers' experiences. Verbalization and conceptualization can also mean various things to various people at the emotional level (see Efland, 1979).

Naturally, the objectives and contents of art education determine the realization of evaluation. Still, every art teacher has to face situations in which there are many possible solutions. Even the criteria and targets of evaluation can be specified in many ways starting from the technical quality of the work of art all the way to the esthetical side, expression, and creativity.

In Finland, art teachers do evaluations based on their own expertise and interpretations while theoretical subjects have different summative standards, and tests have taken root. In addition, theoretical school subjects often seem to be valued more significant. Can evaluation have connection to the appreciation of a subject? Karen Hamblen discussed this in her article called "If it to be tested; it will be taught: a rationale worthy of examination" (1988). In Hamblen's opinion, rigorous evaluation methods can be the means to legitimate art education. Her basic idea is that 
when the evaluation of art education becomes systematic, art will become more equal to other school subjects. What is problematic in Hamblen's ideas is that the use of careful measurement and evaluation tools can limit the offering of art education. The core elements of art, individuality, originality, and creativity, could disappear from art education because of systematized evaluation. Evaluation is always possible but not all can be measured in an exact manner.

Hardly, the purpose of evaluation is just to know whether pupils have learned what they were supposed to learn. In fact, pupils may have learned something else, something unpredicted, too. "It's one thing to ask, 'Did the student learn what (he or I) intended?' It is another to ask, 'What did the student learn?'” (Eisner 1972, p. 211).

To conclude, the problems of evaluation might be the core questions of art education. The wide-ranging and multidimensional nature of the subject makes the finding of solutions more difficult (see Bianchi 2011; Räsänen 2005).

\subsection{Socialization in the Professional Community}

Socialization in the school culture and the professional community of art teachers is a part of teacherhood in art education. The school community can include many cultures and their values, norms, and roles determine how the community acts (see Randless, 2011).

Moreover, work communities have many kinds of work role expectations (Andrews \& Lewis, 2002). They include both official and unofficial roles, and roles related to the task, emotions, and power. Role and emotional structures reflect on the atmosphere, culture, and art teachers' satisfaction with the work and feeling of acceptance. This strengthens the sense of solidarity and security. On the other hand, this can also lead to a situation in which art teachers stick to old habits and thus prevent creativity and reformations in the school community.

Usually, an art teacher is the only art teacher of the school in Finland. He or she is responsible for the development and planning of the subject of art at his or her school (Crow \& Pounder, 2000). This situation has its advantages and disadvantages. The art teacher's work may be independent but he or she has to bear the responsibility alone. Increased opportunities of having optional subjects has made art teachers worried: art has to compete with other subjects and this may result in ways of defending the position and interests of the subject that do not make the best premises for teacher collaboration in the renewing school (Scribner, Sawyer, Watson, \& Myers, 2007).

It is important how students perceive the school subject of art. Several studies have shown that students usually like art very much (Thompson, 2005). Despite being a pleasing subject, art is not considered a very "important" subject in Finnish schools (Anttila, 2006; Jussila \& Rautiainen, 1990; Pohjakallio, 2005). The appreciation of art varies among students and teachers: At the one end, art is seen as a rich and nuanced subject that strengthens creativity, while the other end considers the subject unnecessary waste of time.

\section{Discussion}

Teacherhood in art education means a constant process of information seeking and decision-making. The teacher has to increase his or her knowledge about art and find solutions to the dilemmas at work. Haavio wrote already in 1954 that a teacher is an eternal pupil. Today, the teacher's way of developing has been described with the concept of teacher-researcher (May, 1993). Indeed, "teacher as researcher" movement has given impetus to many projects and networks consisting of teachers researching their work. The concept of teacher-researcher can also be seen as a state of mind or an attitude aiming at achieving better self-awareness through research on one's own work and developing teacherhood through understanding one's own action.

Studies provided to the Masters of Art by the art teacher education program at the Faculty of Art and Design at the University of Lapland have been regarded as significant means of developing teacherhood in art education and practices of realizing art education. The research approach and scientific thinking help art teachers to analyze their situational and concrete experience-based knowledge. Indeed, Kinchelou (1991) points out how most teachers use research-based methods and develop their teaching and themselves. They plan, reflect, question, look for options, experiment, and create various solutions, and observe, test, and evaluate their solutions - at its best, it resembles research-oriented action.

If the art teacher's pedagogical thinking is hesitant or conflicting with the prevailing school culture, it can be difficult to follow professional practices (see Lindfors, 2010). Especially, if the teacher has just recently graduated and does not yet have clear methods or has not yet adopted any educational philosophy, the teacher may find it alienating if being left without support or acceptance at the work place. On the other hand, art teachers, who have a clear understanding of the goals and contents of their work, can handle their work without support by leaning on their 
strong professional identity. The ideal situation is the one where the art teacher being the expert of his or her field can adjust to the necessary norms of the school but maintains his or her personal ways of doing and thus enriches the operation of the school.

Nor do art teachers have just one professional role to adopt but there are contradictory and competing discourses of various professional practices (Danielewicz, 2001). Unquestionably, the offering of art education is irreplaceable: In the learning environment provided by art education, skills that may prove valuable not only to art, but also for example, balance development, mental well-being, science, economic life, and overall societal development, will grow and develop (Paksuniemi, Uusiautti, \& Määttä, 2012). But without art teachers who have been successfully socialized in their profession at all levels presented in this paper the goal will not be reached.

Consequently, in order to be able to promote art education and art education teachers' training, the essence of teacherhood in art education has to be analyzed and defined. For example in Finland, art teachers are obliged to justify and give reasons for art education (Pohjakallio, 2005). The purpose of this review was to contribute to this discussion by introducing the framework through which the multidimensional nature of teacherhood in art education can be better understood and dissected. We used the art teacher training provided at the Unversity of Lapland as the example case and basis of the practical knowledge of the phenomenon.

\section{References}

Addison, N. (2011). Moments of intensity: affect and the making and teaching of art. International Journal of Art \& Design Education, 30(3), 363-378. http://dx.doi.org/10.1111/j.1476-8070.2011.01729.x

Anderson, C. H. (1981). The identity crisis of the art educator: Artist? Teacher? Both? Art Education, 34(4), 45-46.

Andrews, D., \& Lewis, M. (2002). The experience of a professional community: Teachers developing a new image of themselves solves and their workplace. Educational Research, 44(3), 237-254.

Anttila, E. (2006). Taiteen voimalla: Taidekasvatuksen mahdollisuudet suomalaisessa peruskoulussa [With the power of art: the possibities of art education in the Finnish elementary education]. Kasvatus, 37, 1.

Atkinson, D. (2012). Contemporary art and art in education: The new, emancipation and truth. International Journal of Art \& Design Education, 31(1), 5-18. http://dx.doi.org/10.1111/j.1476-8070.2012.01724.x

Ball, L. (1990). What role: Artist or teacher? Art Education, 43(1), 54-59.

Beijaard, D. (1995). Teachers' prior experiences and actual perceptions of professional identity. Teachers and Teaching: Theory and Practice, 1(2), 281-294.

Beijaard, D., Meijer, P. C., \& Verloop, N. (2004). Reconsidering research on teachers' professional identity. Teaching and Teacher Education, 20(2), 107-128. http://dx.doi.org/10.1016/j.tate.2003.07.001

Bianchi, J. (2011). Intercultural identities: Addressing the global dimension through art education. International Journal of Art \& Design Education, 30(2), 279-292. http://dx.doi.org/10.1111/j.1476-8070.2011.01697.x

Bingham, C. (2005). The hermeneutics of educational questioning. Educational Philosophy and Theory, 37, 553-565. http://dx.doi.org/10.1111/j.1469-5812.2005.00140.x

Boud, D., Keogh, R., \& Walker, D. (1989). Reflection: Turning experience into learning. London: Kogan Page.

Clayson, D. E. (2008). Student evaluations of teaching: Are they related to what students learn? A meta-analysis and review of the literature. Journal of Marketing Education, 31(1), 16-30. http://dx.doi.org/10.1177/0273475308324086

Crow, G. M., \& Pounder, D. G. (2000). Interdisciplinary teacher teams: Context, design, and process. Educational Administration Quarterly, 36(2), 216-254. http://dx.doi.org/10.1177/0013161X00362004

Cygnaeus, U. (1910). Uno Cygnaeuksen kirjoitukset Suomen kansakoulun perustamisesta ja järjestämisestä [Uno Cygnaeus's writings about the foundation and organization of the Finnish elementary school]. Helsinki: Kirjayhtymä.

Daichendt, G. J. (2011). The nineteenth-century artist-teacher: A case study of George Wallis and the creation of a new identity. International Journal of Art \& Design Education, 30(1), 71-80. http://dx.doi.org/10.1111/j.1476-8070.2011.01673.x

Daichendt, G. J., \& McDougall, H. (2011). Artist- teacher: A philosophy for creating and teaching. International 
Journal of Art \& Design Education, 30(2), 328. http://dx.doi.org/10.1111/j.1476-8070.2011.01698.x

Danielewicz, J. (2001). Teaching selves: identity, pedagogy and teacher education. Albany, NY: State University of New York Press.

De Backer, F., Lombaerts, K., De Mette, T., Buffel, T., \& Elias, W. (2012). Creativity in artistic education: Introducing artists into primary schools. International Journal of Art \& Design Education, 31(1), 53-66. http://dx.doi.org/10.1111/j.1476-8070.2012.01715.x

Eckhoff, A. (2008). The importance of art viewing experiences in early childhood visual arts: The exploration of a master art teacher's strategies for meaningful early arts experiences. Early Childhood Education Journal, 35, 463-472. http://dx.doi.org/10.1007/s10643-007-0216-1

Efland, A. (1979). Conceptions of teaching in art education. Art Education, 32(4), 21-33.

Efland, A. (2004). Emerging visions of art education. In E. W. Eisner, \& M. D. Day (Eds.), Handbook of research and policy in art education (pp. 691-700). Mahwah, NJ: Lawrence Erlbaum Associates.

Eisner, E. (1972). Educating artistic vision. New York, NY: MacMillan Publishing Company.

Eisner, E. W. (1989). The art of educational evaluation: A personal view. London: Falmer Press.

Eisner, E. (1991). The enlightened eye. Qualitatitive inquiry and the enhancement of educational practice. New York, NY: MacMillan Publishing Company.

Eisner, E. W. (2002). What can education learn from the arts about the practice of education. Journal of Curriculum and Supervision, 18(1), 4-16.

Gadamer, H.-G. (2004). Hermeneutiikka: Ymmärtäminen tieteissä ja filosofiassa [Hermeneutics. Understanding in sciences and philosophy]. Tampere: Vastapaino.

Garnet, D. (2012). Art education theory and practical experience: My journey as an art educator and amateur theorist. Teaching Artist Journal, 10(4), 222-228. http://dx.doi.org/10.1080/15411796.2012.714205

Garvis, S. (2012). A self-study in teacher education: Learning to teach in higher education after teaching the arts to young children. US-China Education Review, B(3), 298-304.

Gude, O. (2004). Postmodern principles: In search of a 21st century art education. Art Education, 57(1), 6-14.

Hall, J. (2010). Making art, teaching art, learning art: Exploring the concept of the artist teacher. International Journal of Art \& Design Education, 29(2), 103-110. http://dx.doi.org/10.1111/j.1476-8070.2010.01636.x

Hamblen, K. (1988). If it is to be tested: It will be taught: A rationale worthy of examination art education. Art Education Association, 41(5), 57-62.

Hounsell, D. (2003). Student feedback, learning, and development. In M. Slowey \& D. Watson (Eds.), Higher education and the life course (pp. 67-78). Maidenhead: Open University Press.

Hunt, C. S., \& Handsfield, L. J. (2013). The emotional landscapes of literacy coaching: Issues of identity, power, and positioning. Journal of Literacy Research, 45(1), 47-86. http://dx.doi.org/10.1177/1086296X12469969

Huuhtanen, P. (1984). Mitä on taidekasvatus? Taidekasvatuksen esteettis-käsitteelliset perusteet [What is art education? The esthetic-conceptual premises of art education]. Jyväskylä: University of Jyväskylä.

Irwin, R. L., \& O'Donoghue, D. (2012). Encountering pedagogy through relational art practices. International Journal of Art \& Design Education, 31(3), 221-236. http://dx.doi.org/10.1111/j.1476-8070.2012.01760.x

Jarvis, P. (1999). The practitioner researcher: Developing theory from practice. San Francisco, CA: Jossey-Bass Publichers.

Jolley, R., \& Zhang, Z. (2012). How drawing is taught in Chinese infant schools. International Journal of Art \& Design Education, 31(1), 30-43. http://dx.doi.org/10.1111/j.1476-8070.2012.01726.x

Jussila, J., \& Rautiainen, M. (1990). Kuvaamataito oppiaineena: kuudesluokkalaisten asennoituminen, harrastaneisuus ja tietojen hallinta [Art as a school subject: sixth-graders' attitude, hobbyism, and mastery of knowledge]. (An unpublished Master's thesis, University of Lapland, Rovaniemi, Finland.)

Kangas, R. (1995). "Vaikutti intuitiivisesti". Luokanopettajat ja taiteilijat lasten piirustusten ja maalausten arvioijina ["Affected me intuitively". Classroom teachers and artists evaluating children's drawings and paintings]. (Master's thesis, University of Lapland, Rovaniemi, Finland.) 
Kakkori, L. (2009). Hermeneutics and phenomenology problems when applying hermeneutic phenomenological method in educational qualitative research. Paideusis, 18(2), 19-27.

Kinchelou, J. (1991). Teachers as researchers. Qualitative inquiry as a path to empowerment. London: Falmer Press.

Kirlew, S. (2011). "But when are they going to produce some 'artwork?" Against pastiche: Issue-based art and authorship within the key stage 3 curriculum. International Journal of Art \& Design Education, 30(3), 379-388. http://dx.doi.org/10.1111/j.1476-8070.2011.01721.x

Korkeakoski, E. (1998). Lasten ja nuorten taidekasvatuksen tuloksellisuus peruskoulussa ja lukiossa: taidekasvatuksen painotukset, opettajien kelpoisuudet, opetusresurssit, oppimistulokset ja kehittämistarpeet [The effectiveness of art education of children and the youth in elementary education and upper secondary education: the emphases of art education, teachers' qualification, resources for teaching, learning results, and developmental needs]. Helsinki: National Board of Education.

Korthagen, F. A. J. (2004). In search of the essence of a good teacher: Towards a more holistic approach in teacher education. Teaching and Teacher Education, 20(1), 77-97.

La Porte, A. M., Speirs, P., \& Young, B. (2008). Art curriculum influences: A national survey. Studies in Art Education, 49(4), 358-370.

Laitinen, S. (2006). Miksi kuvataidetta opetetaan koulussa ja mitä opettajan tulisi siitä tietää ja osata? [Why to teach fine arts at school and what should a teacher know about it?] In R. Jakku-Sihvonen (Ed.), Taide- ja taitoaineiden opetuksen merkityksiä [Meanings of art education] (pp. 33-45). Helsinki: Theatre Academy Helsinki.

Lindfors, E. (2010). The dilemma of arts and crafts: Do teachers have the competence to teach? Helsinki: University of Helsinki.

Lindström, L. (2011). The multiple faces of visual arts education. International Journal of Art \& Design Education, 30(1), 7-17. http://dx.doi.org/10.1111/j.1476-8070.2011.01688.x

Lindström, L. (2012). Aesthetic learning about, in, with and through the arts: A curriculum study. International Journal of Art \& Design Education, 31(2), 166-179. http://dx.doi.org/10.1111/j.1476-8070.2012.01737.x

May, W. (1993). Teachers -as- researchers or action research: What is it, and what good is it for art education? Studies in Art Education, 34(2), 114-126.

MacDonald, S. W. (1998). Post-it culture: Postmodernism and art design education. Journal of Art and Design Education, 17(3), 227-235.

Murray, H. G., Rushton, J. P., \& Paunonen, S. V. (1990). Teacher personality traits and student instructional ratings in six types of university courses. Journal of Educational Psychology, 82(2), 250-261. http://dx.doi.org/10.1037/0022-0663.82.2.250

Määttä, K. (1994). Kuvaamataidon opiskelijasta/opettajasta taiteen tutkijaksi [From the student/teacher of art education into art researcher]. In M. Tuominen (ed.), William Blake, Pekka Puupää ja hän eli keskusteluja intuitioista, oivalluksesta ja analyysistä [William Blake, Pekka Puupää and him: discussions of intuition, insight, and analysis] (pp. 83-97). Rovaniemi: University of Lapland.

Määttä, K. (1998). Kuvaamataidon opetus tutkimuksen kohteena. Mitä kuvaamataidon opetuksen koulutusohjelman opiskelijat ovat tutkineet [Teaching of art education as the target of research. What have students of art education researched?] Rovaniemi: University of Lapland.

Määttä, K. (Ed.) (2001). Kuvaamataidon opettajuuden näkökulmia [Perspectives to teacherhood in art education]. Rovaniemi: University of Lapland.

Määttä, K., \& Uusiautti, S. (2011). Pedagogical love and good teacherhood. In Education, 17(2). Retrieved from: http://ineducation.ca/article/pedagogical-love-and-good-teacherhood

Paksuniemi, M., Uusiautti, S., \& Määttä, K. (2012). From teachers into multiply skilled persons: How was art education implemented at a Finnish teacher training college in 1921-1970? International Journal of Research Studies in Education, online First. http://dx.doi.org/10.5861/ijrse.2012.143

Page, T. (2012). A shared place of discovery and creativity: Practices of contemporary art and design pedagogy. International Journal of Art \& Design Education, 31(1), 67-77. http://dx.doi.org/10.1111/j.1476-8070.2012.01732.x 
Parsons, S. A. (2012). Adaptive teaching in literacy instruction. Case studies of two teachers. Journal of Literacy Research, 44(2), 149-170. http://dx.doi.org/10.1177/1086296X12440261

Pavlou, V. (2004). Profiling primary school teachers in relation to art teaching. International Journal of Art \& Design Education, 23(1), 35-47. http://dx.doi.org/10.1111/j.1476-8070.2004.00380.x

Pohjakallio, P. (2005). Miksi kuvista? Koulun kuvataideopetuksen muuttuvat perustelut [Why art education? The changing justifications of art education at school]. Helsinki: Taideteollinen korkeakoulu.

Pohjakallio, P. (2009). Kuvataidekasvatuksen historiaa tutkimassa [Researching the history of art education]. Kasvatus \& Aika, 3(3), 140-151.

Randles, C. (2009). "That's my piece, that's my signature, and it means more. "Creative identity and the ensemble teacher/arranger. Research Studies in Music Education, 31(1), 52-68. http://dx.doi.org/10.1177/1321103X09103631

Randles, C. (2011). The "Hero's journey": A way of viewing music teacher socialization. Journal of Music Teacher Education, 22(1), 11-19. http://dx.doi.org/10.1177/1057083711403000

Ruohotie, P. (1996). Professional growth and development. In K. Leithwood, J. Chapman, D. Corson, P. Hallinger, \& A. Hart (Eds.), International handbook of educational leadership and administration (pp. 419-445). New York, NY: Springer.

Räsänen, M. (2005). Multi-roled and skilled teachers of art. International Journal of Education Through Art, 1(1), 53-63. http://dx.doi.org/10.1386/etar.1.1.53/1

Räsänen, M. (2009). Taide, taito, tieto - ei kahta ilman kolmatta [Art, skill, and knowledge go together]. In A. Aro, M. Hartikainen, M. Hollo, H. Järnefelt, E. Kauppinen, H. Ketonen, M. Manninen, M. Pietilä, \& P. Sinko (Eds.), Taide ja taito -kiinni elämässä! [Art and skills - attached to life] (pp. 28-39). Helsinki: National Board of Education.

Schmidt, M., \& Canser, J. (2006). Clearing the fog. Constructing shared stories of a novice teacher's journey. Research Studies in Education, 27(1), 55-68. http://dx.doi.org/10.1177/1321103X060270010601

Scribner, J. P., Sawyer, R. K., Watson, S. T., \& Myers, V. L. (2007). Teacher teams and distributed leadership: A study of group discourse and collaboration. Educational Administration Quarterly, 43(1), 67-100. http://dx.doi.org/10.1177/0013161X06293631

Siegesmund, R. (1998). Why do we teach art today? Conceptions of art education and their justification. Studies in Art Education, 39(3), 197-214.

St. John, M. (1985). Criticism and its use in evaluation. Guide number 18. Washington, DC: National Institute of Education.

Stanhope, C. (2011). The artist-teacher in the classroom and changes in the teacher-student relationship, with reference to the issue of censorship. International Journal of Art \& Design Education, 30(3), 389-397. http://dx.doi.org/10.1111/j.1476-8070.2011.01723.x

Tatto, M. T. (2006). Education reform and the global regulation of teachers' education, development and work: A cross-cultural analysis. International Journal of Educational Research, 45(4), 231-241. http://dx.doi.org/10.1016/j.ijer.2007.02.003

Thompson, C. M. (2005). Under construction: Images of the child in art teacher education. Art Education, 58(2), 18-23.

Uusiautti, S., \& Määttä, K. (2013). How to train good teachers in Finnish Universities? Student teachers'study process and teacher educators' role in it. European Journal of Educational Research, 1(4), 339-352.

Thornton, A. (2005). The artist teacher as reflective practitioner. International Journal of Art \& Design Education, 24(2), 166-174. http://dx.doi.org/10.1111/j.1476-8070.2005.00437.x

Thornton, A. (2011). Being an artist teacher: a liberating identity? International Journal of Art \& Design Education, 30(1), 31-36. http://dx.doi.org/10.1111/j.1476-8070.2011.01684.x

Uimonen, A. (1994). Tekstuaalisia järjestelmiä vai pastaa pizzalla [Textual systems of pasta with pizza?] Helsingin Sanomat, 9 September 1994.

$\begin{array}{lllll}\text { University } & \text { (2013). Lapland. } & \text { Retrieved }\end{array}$ 
http://www.ulapland.fi/InEnglish/Units/Faculty_of_Art_and_Design/Studies.iw3

van Manen, M. (1991). The tact of teaching: The meaning of pedagogical thoughtfulness. London: Althouse Press.

Watts-Taffe, S. (Barbara) Laster, B. P., Broach, L., Marinak, B., McDonald Connor, C., \& Walker-Dalhouse, D. (2013). Differentiated instruction: Making informed teacher decisions. Reading Teacher, 66(4), 303-314. http://dx.doi.org/10.1002/TRTR.01126

Westerman, D. (1991). Expert and novice teacher decision making. Journal of Teacher Education, 42(4), 292-305. http://dx.doi.org/10.1177/002248719104200407

Wild, C. (2011). Making creative spaces: The art and design classroom as a site of performativity. International Journal of Art \& Design Education, 30(3), 423-432. http://dx.doi.org/10.1111/j.1476-8070.2011.01722.x

Williamson McDiarmid, G., \& Clevenger-Brigth, M. (2008). Rethinking teacher capacity. In M. Cochran-Smith, S. Feiman_Nemser, \& D. McIntyre (Eds.) Handbook of research on teacher education. Enduring questions in changing contexts (pp. 697-705). New York/Abingdon: Routledge//Taylor \& Francis.

Zeichner, K. M., \& Noffke, S. E. (2001). Practitioner research. In V. Richardson (Ed.), Handbook of research of teaching (pp. 298-330). Washington, DC: American Educational Research Association.

Zombylas, N. (2007). Emotional ecology: The intersection of emotional knowledge and pedagogical content knowledge in teaching. Teaching and Teacher Education, 23, 355-367. 